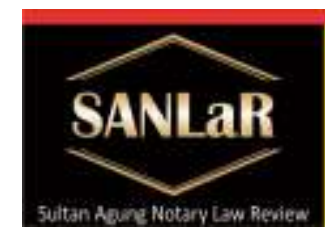

Volume 3 No. 3, September 2021
Sultan Aqung

Notary Law Review

Agreements on Individual... (Heni Astuti \& Bambang Tri

\title{
Agreements on Individual Accounts using Guarantee of Certificate which Bound by Selling Deed
}

\author{
Heni Astuti ${ }^{*}$ and Bambang Tri Bawono**) \\ ${ }^{*}$ Faculty of Law, Universitas Islam Sultan Agung (UNISSULA) Semarang, E-mail: \\ heniastuti94@gmail.com
}

${ }^{* *}$ Faculty of Law, Universitas Islam Sultan Agung (UNISSULA) Semarang, E-mail:
bambang@unissula.ac.id

Abstract. In ancient times it was customary for people to make loan agreements involving land. Land is also commonly loaned to other people under a lease agreement. In Indonesia, lending and borrowing agreements are regulated in Article 1754 of the Civil Code concerning debts and receivables. Accounts payable begins with an agreement between two legal subjects called debtors and creditors, then accompanied by the delivery of objects as collateral. Today, in the Limbangan sub-district, Kendal regency, Central Java, there is a practice of individual debt agreements with guaranteed land and building certificates with an area of $255 \mathrm{~m}^{2}$ which are bound not by a Mortgage Deed (APHT), but using a Sale and Purchase Deed (AJB) and legalized by a Notary as Land Deed Maker Official (PPAT). The purpose of this study was to determine and analyze the validity of an individual debt agreement using a certificate guarantee bound by a Sale and Purchase Deed in Kendal regency. Another objective is to find out and analyze the responsibilities of a Notary to the making and registration of a Sale and Purchase Deed which is used as a guarantee for an individual debt agreement in Kendal regency. This study uses a research method in the form of Sociological Juridical which is also called field research. According to its nature, the research to be conducted has a descriptive analytical research type. The type of data used is primary data and secondary data, and data collection tools used are field studies and literature studies. Based on the discussion discussed in this study and the data that has been collected that the validity of the guarantee of property rights to land bound using a deed of sale and purchase in Kendal regency is legal and can be carried out according to legal certainty theory, as long as the main agreement of the guarantee is not Contrary to the provisions stipulated in Article 1320 of the Civil Code regarding the legal terms of the agreement, namely agreement, competence, a certain matter and a lawful cause. The powers and responsibilities of a notary in Kendal regency are in accordance with the theory of authority that has been described, namely attributive authority, delegative authority, and mandate authority and in carrying out his 
position to make and register the sale and purchase deed has been meticulous and thorough as mandated by article 16 paragraph (1) UUJN. However, the notary should still propose a guarantee agreement on land and buildings tied using mortgage rights not with a sale and purchase deed so that unwanted things do not happen that can harm both parties even though in fact the duties or responsibilities of the notary are basically not responsible for the contents. The deed made before him because the contents of the deed are the will and agreement desired by the parties.

Keywords: Accounts; Payable; Agreements; Collaterals; Sale; Purchase.

\section{Introduction}

In ancient times it was customary for people to make loan agreements involving land. For example, Ter Haar, a customary law scholar from the Netherlands, who has conducted research on customary law in Indonesia, has found a land loan agreement in which a landowner lends his land to another person for a place to live or to cultivate under a borrow-to-use agreement. ${ }^{1}$ Land is also commonly lent to other people with lease agreements or profit sharing. The law that applies in these agreements is customary law. According to customary law, a land lease agreement is an agreement in which the land owner gives permission to another person to use the land as a place of business for a certain time, by receiving a certain amount of money as rent; whereas in a profit sharing agreement, a land owner makes an agreement with another person to work on his land with an agreement that the results of the land are divided in half. ${ }^{2}$

Agreement In general, it is also known as an agreement, because the two parties agree to do something. It can be said that between the agreement and the agreement is the same meaning where the agreement or what is called Overeenkomsten is "an agreement between two or more parties regarding their assets, which aims to bind both parties".

Article 1338 of the Civil Code states that "all agreements made legally apply as law for those who make them. These agreements cannot be withdrawn other than by agreement of both parties, or for reasons which are stated to be sufficient by law. Agreements must be executed in good faith".

\footnotetext{
${ }^{1}$ Ter Haar, , Asas-asas dan Susunan Hukum Adat, terjemahan Soebakti Poespononoto, Pradnya Paramita, Jakarta, 2001, p. 113.

${ }^{2}$ Ibid, p. 225.
} 
The loan agreement in Indonesia is regulated in Article 1754 of the Civil Code concerning debts and receivables. Accounts payable begins with an agreement between two legal subjects called debtors and creditors, then accompanied by the delivery of objects as collateral.

The land rights that are used as collateral in the credit agreement must be bound by a deed of encumbrance of mortgage rights (APHT), and this deed is made before the official making the land deed (PPAT) in accordance with the duties and authorities stated in the UUHT. ${ }^{3}$

Currently, in the Limbangan sub-district, Kendal regency, Central Java, there is a practice of individual debt agreements with land and building certificates guaranteed not by a Mortgage Deed (APHT), but using a Sale and Purchase Deed $(A J B)$ and ratified by a Notary as a Deed Making Officer. Land (PPAT).

The loan agreement guarantees land and building certificates covering an area of $255 \mathrm{~m} 2$ made by agreement of both parties, namely the first party with the initials tn.(B) as the lender/debt can also be called the holder of the object of collateral, and the second party with the initials tn.(W) as the owner of the certificate of land and building covering an area of $255 \mathrm{~m} 2$ can also be called the giver of the object of guarantee. The guarantee process is bound in the form of a Sale and Purchase Deed (AJB) which is legalized by a Notary so that there is a transfer of certificate ownership rights from the second party to the name of the first party.

Based on the description of the case above, it can be risky for the occurrence of misuse of the condition of the sale and purchase of land and buildings in the debt agreement, because the guarantee agreement made using the Sale and Purchase Deed (AJB) does not use Mortgage Rights, that the certificate has indirectly become the property of the party. The second and legally valid in Indonesia, while the first party no longer has the right to the ownership of the land and building certificates.

The formulation of the problem in this study are: How is the validity of an individual debt guarantee agreement using a certificate guarantee bound by the Sale and Purchase Deed and the responsibility of the Notary to the making and registration of the Guarantee Deed.

${ }^{3}$ Purwahid Patrik dan Kashadi, Hukum Jaminan, Badan Penerbit Universitas Diponegoro, Semarang, 2009, p. 115 


\section{Research Methods}

This research uses a sociological juridical research method which can also be called field research, which is to examine the applicable legal provisions and what is happening in reality in the community or in other words a research conducted on the actual situation or real conditions that occur in the community with the intention of knowing and find the facts and data needed, after the data needed is collected then leads to problem identification which ultimately leads to problem solving. ${ }^{4}$ Sources and Types of Data used in this study in the form of primary data and secondary data. Primary data contains observations and interviews while secondary data contains primary legal materials, secondary legal materials, and tertiary legal materials. ${ }^{5}$ Data was collected by means of field studies and literature studies. ${ }^{6}$ The results of the research data analysis will be interpreted using qualitative data analysis methods, namely describing and interpreting the data that has been collected, so that a general and comprehensive picture of the actual situation is obtained. ${ }^{7}$

The purpose of this journal research is first to find out and analyze the validity of an individual debt agreement using a certificate guarantee bound by a Sale and Purchase Deed in Kendal regency and secondly to find out and analyze the responsibilities of a Notary to the making and registration of a Sale and Purchase Deed which is used as a guarantee of the agreement individual debts in Kendal regency.

\section{Result and Discussion}

\subsection{The validity of the Guarantee of Ownership of Land based on the Deed of Sale and Purchase in Kendal Regency}

The results of interviews with the first party (Mr. B) and the second party (Mr. $\mathrm{W})$, the chronology of this case is the beginning of the second party borrowing IDR 200 million from the first party with land and building collateral covering an area of $255 \mathrm{~m} 2$. Both parties went to a Notary in Kendal regency to make a debt agreement. On October 24, 2015 both parties agreed to make a payable agreement before a notary bound using a Sale and Purchase Deed. The land that is used as collateral, stands on Certificate of Ownership (SHM) No. 1316, located in Ds Limbangan Kec Limbangan Kendal Regency on behalf of Mr (W).

\footnotetext{
${ }^{4}$ Bambang Waluyo, Penelitian Hukum Dalam Praktek, Sinar Grafika, Jakarta, 2002, p. 15-16.

${ }^{5}$ Amiruddin, Introduction to Legal Research Methods, PT Raja Grafindo Persada, Jakarta, 2006, p.30.

${ }^{6}$ Amiruddin, Pengantar Metode Penelitian Hukum, PT Raja Grafindo Persada, Jakarta, 2006, p.119

${ }^{7}$ Lexy J. Moleong, Metodologi Penelitian Kualitatif Edition Revision, Remaja Rosdakarya, Bandung, 2009, p. 186.
} 
The contents of the agreement are as follows:

1. The first party, namely Mr. (B) gave a debt or loan of money to the second party, namely Mr. (W) in the amount of IDR 200,000,000 (two hundred million rupiah).

2. The second party or Mr. (W) is able to return the end of December 2016, with the guarantee of a Certificate of Ownership (SHM) of land and buildings covering an area of $255 \mathrm{~m} 2$ number 1316 on behalf of the second party.

3. Both parties agreed that the guarantee agreement was bound in the form of a Sale and Purchase Deed (AJB) which was legalized by a Notary so that there was a transfer of ownership rights to the land and building certificates covering an area of $255 \mathrm{~m} 2$ on behalf of the second party to the name of the first party (transfer of name).

4. The loan/debt agreement agreement will be repaid within one year. If at the end of December 2016 tn (W) has not been able to return it then the first party, namely tn (B) can proceed legally and the second party, namely tn (W) can be processed.

Furthermore, the first party and the second party have carried out the contents of the loan agreement. One year later but until the time limit agreed in the agreement has passed, the second party does not return the debt to the first party. On March 23, 2017, the first party has sent a warning to the second party to carry out its obligations, but the second party still has not completed the obligation to pay the debt to the first party, so that the second party is called a default on the agreement that has been made. Because the second party has defaulted, then in accordance with the agreement in the agreement dated October 24, 2015, the second party must be punished to surrender the object of the guarantee completely and legally process the object of the guarantee to be on behalf of the first party.

Based on the above case, when viewed from the theory of legal certainty, the first point put forward by Gustav Radbruch is that the law is positive, which means that it is a law, in the deed of sale and purchase agreement made by a notary in this case it contains several articles that must be obeyed by each party, which means that the agreement makes laws which must be obeyed and implemented, then if there is a violation of the law, the first or second party will be subject to the agreed legal sanctions. The second point is that the law is based on facts, that is, it is based on reality. In making the deed of sale and purchase in this study, the notary concerned made based on the agreement of both parties and based on the facts on the ground, The certificate on the land and building covering an area of $255 \mathrm{~m}^{2}$ is truly the property of the second party and a review 
has been carried out on the authenticity of the certificate document on the name, geographical location, boundaries, and size of the land and buildings in question. The third point is that facts must be formulated in a clear way so as to avoid mistakes in meaning. The making of a sale and purchase deed made by a notary in this case is formulated in a clear way, starting from the biodata between each party that is clear and can be accounted for, the contents of the agreement contained have fulfilled the elements of the sale and purchase deed, and the authenticity of the guarantee certificate document. It is also clear in accordance with the facts. The fourth point is that positive law should not be easily changed.

Another discussion is that according to Article 1320 of the Civil Code, it states that the conditions for a valid agreement are valid. In order for a valid agreement to occur, it is necessary to fulfill 4 (four) namely Agree, Proficient, Due to a certain matter, Halal cause. In this case, both parties, namely tn (B) as the first party and tn (W) as the second party, have made an agreement to make an agreement in guaranteeing property rights over the land. Furthermore, both parties have also been proficient in carrying out legal actions in accordance with the provisions of Article 330 of the Civil Code that both parties are over 21 years of age and are legally competent. Then the two parties also made the agreement because there was one thing that was agreed upon, namely a money loan agreement that was charged with a guarantee agreement for land ownership rights,

3.2. The Notary's responsibility for the preparation and registration of the Guarantee Deed which is bound using the Sale and Purchase Deed in Kendal regency

The chronology from the point of view of the Notary who handles this case is On October 19, 2015 There were 2 (two) people who came to the practice where he wanted to apply for a loan agreement that guarantees ownership rights to land and buildings. Namely: the first party (Tn.B) and the second party (Tn.W). Furthermore, Mrs (E) as a Notary and PPAT processes the making of a guarantee agreement submitted by both parties, in the process Notary Mrs (E) gives the choice to both parties to choose the deed to be used in the agreement on 24 october 2015 the guarantee agreement was realized and there was a signing of the agreement which had been agreed by both parties which was bound by the Sale and Purchase Deed. Furthermore, Mrs (E) as a Notary and PPAT in Kendal Regency made and registered the Sale and Purchase Deed on the guarantee agreement that had been agreed between the two parties. The guarantee agreement with the sale and purchase deed has gone through the applicable procedures and is considered valid in accordance with applicable law in Indonesia. 
One year later, there was a default by the second party because it could not pay off a number of debts in accordance with the grace period specified in the agreement so that the second party must be sentenced to surrender the object of guarantee fully and be processed legally. The notary suggested to each party to be able to negotiate again so that there was a consensus that would not incriminate both parties so that in the future neither party would be harmed by each other, but the first party refused because he had spoken several times to negotiate with the second party but the result was still the same, namely the second party asks that the repayment period can be extended, so that in this case the Notary and PPAT who handle the case have been completed because there has been a decision or agreement on the existing guarantee agreement by both parties.

Based on the above case, when viewed from the theory of authority put forward by JG Brouwer and AE Schilder, namely the theory of authority, there are 3 (three) categories of authority, namely attribute authority, delegate authority and mandate authority. Discussing the attribute authority, delegate authority and mandate authority, that the notary Mrs.(E) carries out the mandate given by the State through Act No. 30 of 2004 concerning the Notary Position, namely in ratifying signatures and determining the certainty of the date of the letter under the hand of Mr.( B) and Mr. (W) by registering in a special book, Recording the letters under the hand by registering in a special book, Making copies of the original letters under the hand in the form of copies containing descriptions as written and described in the letter in question, Validating the compatibility of the photocopy of the land and building certificate covering an area of $255 \mathrm{~m}^{2}$ with the original letter, Providing legal counseling in connection with the making of the deed, namely suggesting Mr. one of the agreements between $\mathrm{mr}$.(B) and $\mathrm{mr}$.(W). These powers have been carried out by a notary Mrs. (E) in carrying out her profession as a notary. This shows that all the powers of a notary Mrs.(E) are valid because they are carried out in accordance with applicable law in the form of statutory regulations.

\section{Closing}

Based on the theory of legal certainty and also based on existing law that the guarantee agreement is legally bound by a deed of sale and purchase and not using mortgage rights, but if the second party can pay off on time and there is no default on the debt in question, then the certificate of land that has been guaranteed to the first party will take another name transfer process and can be risky because the guarantee is tied to a deed of sale and not using mortgage rights, meaning the certificate that is guaranteed from the beginning has transferred ownership to the first party as described in the sale and purchase deed that has been made previously, it is feared that there will be misuse of the 
state of the land and building certificate by the first party because indirectly the certificate has become the property of the first party and is legally valid in Indonesia, while the second party has no ownership rights over the land and building certificate. The powers and responsibilities of a Notary in Kendal regency are in accordance with the theory of authority that has been described, namely attributive authority, delegative authority, and mandated authority and in carrying out his position to make and register a sale and purchase deed has been thorough and thorough as mandated by article 16 paragraph (1) UUJN. The notary has also checked the correctness of the documents provided by the appearers and has ensured that the parties are present at the signing of the sale and purchase deed in accordance with the provisions of Article 44 of the UUJN.

\section{References}

Al-Quran and Hadith

Journals:

[1] A Chuasanga, Ong Argo Victoria. (2019). Legal Principles Under Criminal Law in Indonesia and Thailand, Jurnal Daulat Hukum, Vol 2, No 1 (2019) http://jurnal.unissula.ac.id/index.php/RH/article/view/4218

[2] Deen, Thaufiq., Ong Argo Victoria \& Sumain. (2018). Public Notary Services In Malaysia. JURNAL AKTA: Vol. 5, No. 4, 1017-1026. Retrieved from http://jurnal.unissula.ac.id/index.php/akta/article/view/4135

[3] Ong Argo Victoria, Ade Riusma Ariyana, Devina Arifani. (2020). Code of Ethics and Position of Notary in Indonesia. Sultan Agung Notary Law $\begin{array}{llll}\text { Review } & 2 & (4), \quad \text { 397-407, } \quad \text { http://lppm- }\end{array}$ unissula.com/jurnal.unissula.ac.id/index.php/SANLaR/article/view/13536

[4] Yaya Kareng, Ong Argo Victoria, R. Juli Moertiyono. (2019). How Notary's Service in Thailand. Sultan Agung Notary Law Review, 1 (1), 46-56, http://jurnal.unissula.ac.id/index.php/SANLaR/article/view/4435

Books:

[1] Amiruddin, Pengantar Metode Penelitian Hukum, PT Raja Grafindo Persada, Jakarta, 2006

[2] Bambang Waluyo, Penelitian Hukum Dalam Praktek, Sinar Grafika, Jakarta, 2002

[3] Lexy J. Moleong, Metodologi Penelitian Kualitatif Edition Revision, Remaja Rosdakarya, Bandung, 2009

[4] Purwahid Patrik dan Kashadi, Hukum Jaminan, Badan Penerbit Universitas Diponegoro, Semarang, 2009 
[5] Ter Haar, Asas-asas dan Susunan Hukum Adat, terjemahan Soebakti Poespononoto, Pradnya Paramita, Jakarta, 2001

Regulations:

[1] 1945 Constitution of the Republic of Indonesia.

[2] Act No. 2 of 2014 concerning amendments to Act No. 30 of 2004 concerning the Position of a Notary.

[3] Book of Mortgage Law.

[4] Civil Code, State of the Republic of Indonesia Number 76 of 1981.

[5] Government Regulation Number 24 of 1997

[6] Regulation of the Head of the National Land Agency (Perkaban) No. 08 of 2012 concerning Land Registration

[7] The banking law currently in force is Act No. 10 of 1998 concerning Amendments to Act No. 7 of 1992 concerning Banking (State Gazette of the Republic of Indonesia of 1998 Number 182, Supplement to the State Gazette Number 3790). 